\title{
A Comparative Study of Indonesian and Malaysian Monetary Policy
}

\author{
Neni Sri Wulandari \\ Program Studi Ilmu Ekonomi dan Keuangan Islam, FPEB, Universitas Pendidikan Indonesia, Bandung, Indonesia
}

\begin{abstract}
The important role of monetary policy lies in its ability to influence price stability, economic growth, employment opportunities and balance of payments. Therefore it is very important for the central bank to establish monetary policy in a country especially for two developing countries such as Indonesia and Malaysia. The purpose of this study is to determine the implementation of monetary policy in Indonesia and Malaysia. The method used is the study of literature by comparing the monetary policies of Indonesia and Malaysia. The results of this study indicate that Indonesian monetary policy is strongly influenced by interest rates while monetary policy in Malaysia is influenced by direct loans without ties through open tenders, repo transactions, auction of Bank Negara Monetary Notes (BNMN), auction of Bank Negara Interbank Bills (BNIBs) and foreign exchange (FX). The implications of this study are expected to be able to add new inclusions regarding the implementation of monetary policy in Indonesia and Malaysia.
\end{abstract}

Keyword. monetary policy, comparative study, indonesia, malaysia.

Article history. Received January, 2019. Revised March, 2019. Accepted June, 2019

Corresponding author. Email: neni.wulandari@upi.edu

How to cite article. Wulandari, N. S. (2019). A Comparative Study of Indonesian and Malaysian Monetary Policy. The International Journal of Business Review (The Jobs Review), 2(1), 4756. https://doi.org/https://doi.org/10.17509/tjr.v2i1.20468

\section{INTRODUCTION}

The issue of monetary policy instruments is always interesting research to study at this time. The importance of this research is because monetary policy can influence economic growth and financial stability of the country, especially the monetary policy systems of Indonesia and Malaysia which apply a dual monetary policy system (Utomo \& Setiaji, 2012). Using appropriate monetary policy instruments is a must. However, monetary policy instruments issued by the state are not always following the facts on the ground, resulting in the function of monetary policy as state financial stability does not run optimally (Naveed, 2015).

Monetary policy is a policy originating from the central bank in the form of controlling the amount of monetary and/or interest rates to achieve the desired economic goals (Ahmad \& Ismail, 2019). Monetary policy itself is seen as a strong instrument for achieving economic goals such as price stability, employment, balance of payments and sustainable economic growth in the country (Omer, 2019). Besides, there are two classes of monetary policy namely expansionary monetary policy to increase the money supply and contractive monetary policy to reduce the money supply. The central bank itself issued this monetary policy through three instruments, namely Open Market Operations (OMO), discount policy and Statutory Reserves (Magdalena, 2014).

The objectives of monetary policy in Indonesia itself are listed in article 7 of Law no. 3 of 2004 namely achieving and maintaining the stability of the rupiah value where this can be achieved with the presence of monetary stability followed by financial system stability. Therefore, Bank Indonesia sets the policy rate of BI 7DRR (Bank Indonesia 7 Days Repo Rate) as the main policy instrument to influence economic activity (Herianingrum \& Syapriatama, 2016).

47 | The International Journal of Business Review (The Jobs Review) Vol.2 | No.1 | 2019 
Likewise, Malaysia sets the interest rates that borrowers must pay for their loans based on the policies of the Malaysian Central Bank. As long as the economy is also high in inflation, monetary policy will be tightened by withdrawing funds from the banking system and raising interest rates (Simanjuntak \& Santosa, 2019).

The research of (Bosco, Parisio, \& Baldi, 2009) explained that there is a need for relevance and stimulus to studies on comparative studies of policy instruments used in several countries. The comparative study is expected to provide new knowledge for the monetary policy managers in each country. More importantly, monetary policy in one country can be of relevance for use in other countries.

By implementing this double monetary policy, the economic conditions of both Indonesia and Malaysia from year to year showed stable growth. But of course, there are some differences in the implementation of monetary policy both in Indonesia and Malaysia. The difference is caused by differences in the effectiveness of each country's transmission mechanism, the location of different structural transmission mechanisms, the country's financial system, and economic openness in each of the different countries (Antonio, 2014).

Previous empirical study is research (Ascarya, 2012) which discusses the flow of transmission and the effectiveness of dual monetary policy in Indonesia. The results of the study explain that monetary policy in Indonesia that uses a dual monetary system is more effective using the sharia pattern than the conventional pattern. While research (Shah, 2019) which investigates the effectiveness of Islamic bank credit offers in Malaysia and Pakistan. The results show that the offer of Islamic bank credit in Malaysia is more effective compared to the offer of Islamic bank credit in Pakistan.

Other studies that examine monetary policy in Indonesia and Malaysia, including conducted by (Wibowo, 2014) that the benchmark interest rate in setting inflation policy targets in Indonesia is slower when compared to the Singapore and Malaysia benchmark interest rates. Furthermore, research conducted by (Fikri, 2019) the results explain that credit financing is a relevant factor in influencing monetary policy in Indonesia which uses a dual monetary policy system; (Ahmad \& Ismail, 2019) hat gross domestic product can be used as an indicator of monetary taxation; (Chaidir, 2019) explained that the exchange rate is the factor that most influences the inflation rate so that and impacts on monetary policy.

This research is a development from previous research. However, what distinguishes this study from previous research is to compare the monetary policy system in Indonesia and Malaysia. The focus of this research is first to analyze the flow of monetary policy transmission in Indonesia and Malaysia and their impact on economic growth. Second, to see the effectiveness of monetary policy instruments implemented in Indonesia and Malaysia. The results of this study are expected to provide an overview of which monetary policies are most effectively applied in Indonesia and Malaysia.

\section{RESEARCH METHOD}

This research is library research in the field of monetary policy that is with data and qualitative analysis. Therefore to obtain the required data the writer describes and analyzes the object of research, reads and examines various sources from books, journals, and others related to the research topic and can support in this research, to begin to be analyzed and ultimately proven to produce results for pouring in the form of a written report (Ahmadi, 2016).

In this study, the authors describe the monetary policies undertaken by the Indonesian and Malaysian governments and explain the development of monetary policies in Indonesia and Malaysia as well as comparing the monetary policies carried out by the Indonesian and Malaysian governments.

48 | The International Journal of Business Review (The Jobs Review) Vol.2 | No.1 | 2019 
The data used in this study are secondary data obtained from library materials (Subagyo, 2004). Secondary data obtained from relevant research journals, Bank Indonesia monetary bulletins, monetary policy information on the website and Indonesian and Malaysian monetary policy reports published by Bank Indonesia.

Data collection and analysis methods used in this study are qualitative analysis. Qualitative analysis is research whose data are expressed in verbal form and analysis without using statistics, the research steps will be clearly known after the research is completed. So the authors analyze and collect data simultaneously. Furthermore, the collection of data that has been obtained is analyzed using the following methods:

a. The Comparative Method

The comparative method is an analysis carried out by comparing one data with another data or one variable with another variable. Thus the comparative method in this study the authors use to analyze data and then compare the concept of monetary policy in Indonesia with monetary policy in Malaysia.

b. The Inductive Method

Inductive method is a way of thinking from facts, concrete events. The method used in thinking goes from specific to general matters.

\section{RESULTS AND DISCUSSION}

\section{Malaysia Moneter Policy}

Bank Negara Malaysia (BNM) as the central bank sets monetary policy by changing interest rates and adjusting the money supply. The monetary policy instrument normally used by Bank Negara Malaysia is the interest rate at which the BNM issues an Overnight Policy Rate (OPR) or overnight policy rate. OPR is the interest rate set by BNM for financial institutions that lend funds immediately to other financial institutions (Ahmad \& Ismail, 2019).

In 2014, Malaysia's economic condition was strongly influenced by the decline in world commodity prices. Like for example, the decline in global oil prices raises concerns about the country's fiscal position and balance of payments. However, economic conditions continue to show a stable development of 5.5 percent. Besides, financial system stability is also supported by strong financial institutions in terms of risk management (Bank Negara Malaysia, 2015).

Malaysia's efforts to raise the benchmark interest rate in 2014 is to be able to maintain stable economic growth. Besides, the Malaysian central bank also raised the lower and upper limits of the OPR interest curve at 3 and 3.5 percent, respectively (Bank Negara Malaysia, 2015).

Marked by Malaysia's economic growth rate was 4.7 percent at the end of 2018 and Malaysia's benchmark interest rate from 2014 to 2019 remained stable at 3.25 percent (Bank Negara Malaysia, 2019).

Nevertheless, Malaysia's inflation risk in 2015 increased by around 3.2 percent. Inflation that was higher than 2014 was driven by domestic cost factors, namely the adjustment of rising fuel prices that are still unstable, electricity tariffs and the application of goods and services taxes (Bank Negara Malaysia, 2015). This caused the Malaysian central bank to issue a monetary policy that focused on controlling inflation.

Aside from raising interest rates, the Malaysian Government imposes price controls and Anti-Profiteering Acts to strengthen enforcement of the Act and monitor for the wrong 
business people. Also carried out price reforms so that social stability is also achieved (Bank Negara Malaysia, 2015).

In 2016, Malaysia's monetary policy is focused on price stability. This is due to the impact of weaker-than-expected global economic growth and policy uncertainty in the United States and China. Global economic conditions were also exacerbated by the results of the referendum of the British European Union (Brexit) and increased global geopolitical risk.

Therefore, the Malaysian Monetary Policy Committee (MPC) adjusted the monetary accommodative rate by reducing the 2016 interest rate to 3 percent. This adjustment is a preemptive step aimed at ensuring the Malaysian economy continues to be on a stable growth path. At the 3 percent level, interest rates are considered consistent with the policy stance intended for growth prospects as well as inflation (Bank Negara Malaysia, 2016).

Inflation in early 2016 was around 3.5 percent. The high level of inflation in 2016 was the effect of falling oil prices in the previous year. Besides, the application of goods and services tax amid a low energy environment also makes Malaysia's inflation rate increase. Then, another policy launched by the Malaysian central bank is to adjust the weaker ringgit exchange rate. The rest, the Malaysian Monetary Policy Committee remains consistent with monetary policy as in the previous year (Bank Negara Malaysia, 2016).

The implementation of monetary policy is still the same as the previous year in Malaysia. The interest rate remained at 3.62 percent for seven months in 2017. The policy succeeded in boosting Malaysia's economy by 10.9 percent. Likewise, a stable inflation rate is at 3 percent (Bank Negara Malaysia, 2018).

Whereas in 2018, the Malaysian central bank lowered interest rates to 3.25 percent. The policy was put in place to keep up with the growing global trade flow affecting the Malaysian economy. The inflation rate this year is still stable at 3 percent (Bank Negara Malaysia, 2019).

The development of the Malaysian economy over the past five years is as follows:

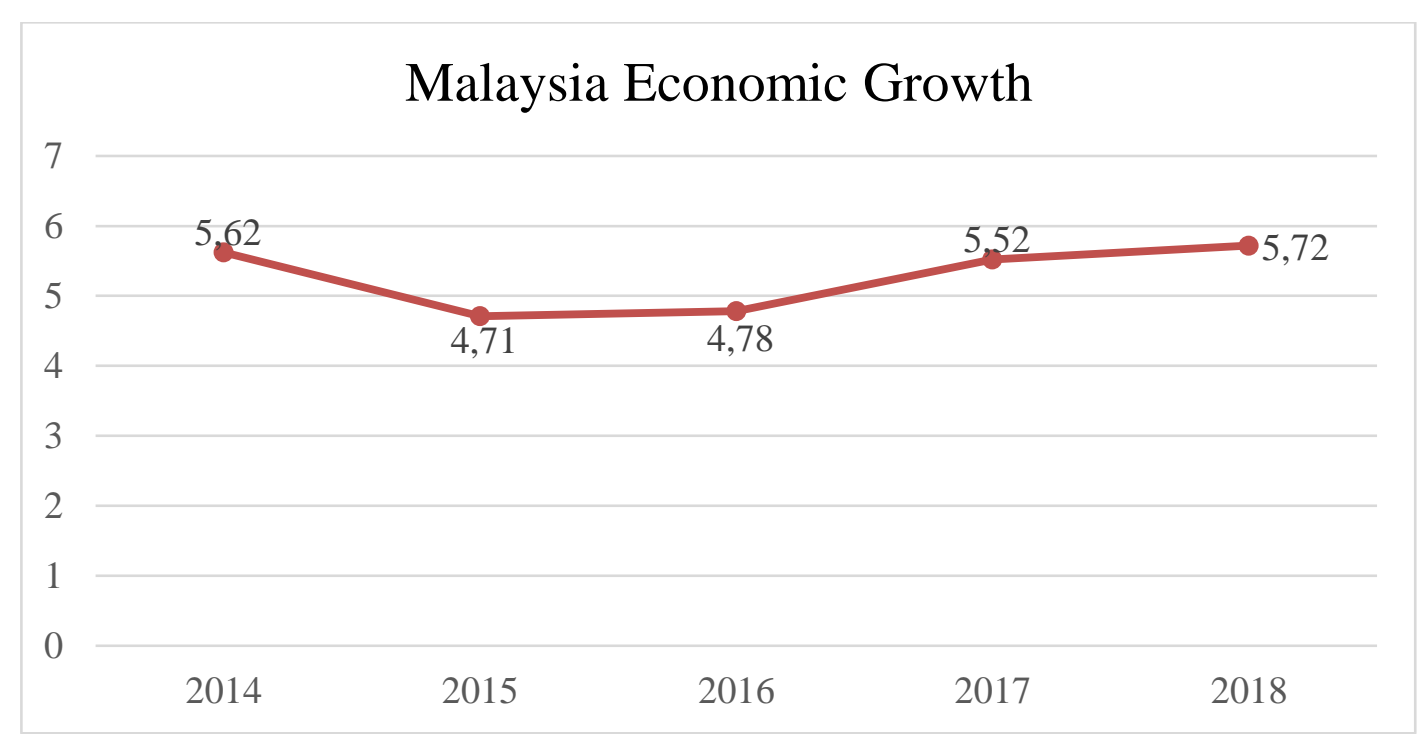

Figure 1. Malaysia Economic Growth

Source: (CEIC Data, 2019)

Indonesia Monetary Policy

Bank Indonesia has implemented a strengthening of the monetary policy framework with the Inflation Targeting Framework (ITF) since 2005. It includes four basic elements namely the use of interest rates as a policy reference rate, anticipatory policy formulation 
processes, more transparent strategies and strengthening of policy coordination together with the government. The targeted inflation rates for the period 2016 to 2018 are 4.0 percent, 4.0 percent and 3.5 percent with a deviation of \pm 1 percent (Bank Indonesia, 2018).

The main monetary instrument applied by Indonesia is the same as Malaysia, namely the determination of interest rates. Through changes in the BI 7 Day Repo Rate (BI 7DRR) which then affects the deposit interest rates and bank credit rates. The transmission mechanism through the interest rate channel can be seen in Figure 2 below:

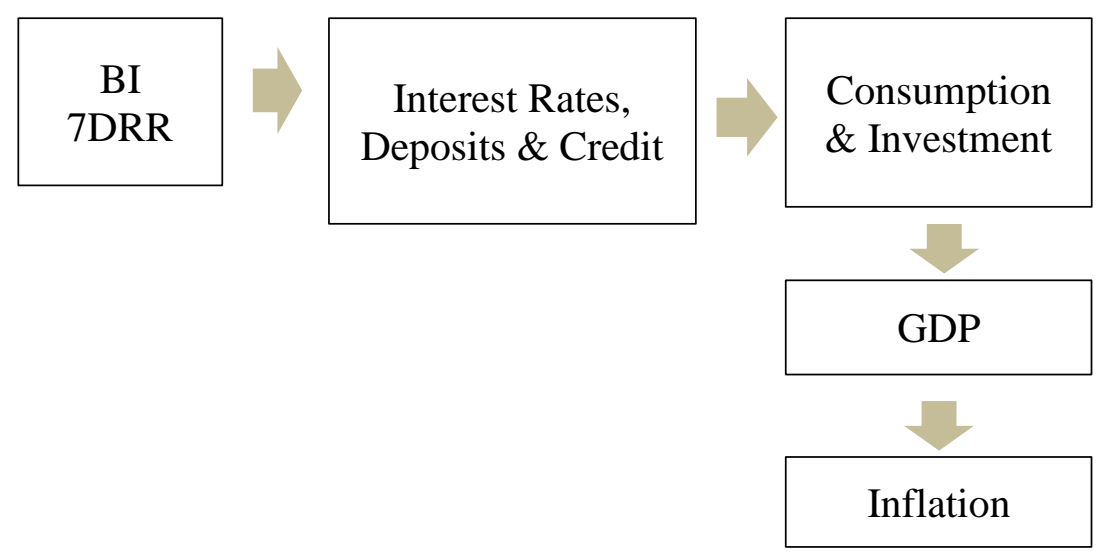

Figure 2. The mechanism for transmitting monetary policy in the interest rate pathway Source: (Bank Indonesia, 2018)

The scheme of the monetary policy transmission mechanism for the interest rate channel in Figure 1, is in line with the monetary policy decided by Bank Indonesia as the central bank in the last five years. In 2014, Indonesia's economy remained stable as in the previous year. This was reflected in the current account deficit which declined and inflation that remained manageable. The current account performance improved this year, supported by a trade balance surplus (Bank Indonesia, 2015).

Nevertheless, the rupiah exchange rate weakened in line with the broad appreciation of the United States dollar. Rupiah weakened by 3.9 percent to Rp. 12,244 per US dollar. Therefore, Bank Indonesia has to deal with ways to reduce imports, especially consumer goods, as well as improve export competitiveness, especially manufacturing (Bank Indonesia, 2015).

In 2015, the central bank relaxed its monetary policy to encourage economic growth. This was due to the improving economic conditions in Indonesia. The increase in economic growth was driven by the role of the government both in consumption and investment in infrastructure and the holding of the elections.

The rupiah exchange rate strengthened in 2015 compared to 2014. The Rupiah managed to strengthen 0.1 percent and closed at the level of Rp. 13,775 per US dollar. The appreciation of the rupiah was supported by increased inflows of foreign capital, especially to the state securities market. Inflation growth slowed to 3.62 percent in the fourth quarter of 2015. So, Bank Indonesia decided to reduce the deposit facility interest rate to 5 percent and lending facility to 7.5 percent (Bank Indonesia, 2016).

The transmission of monetary policy easing through the interest rate channel continued in 2016. Bank Indonesia reduced the BI 7-Day Reverse Repo Rate rate to 5 percent with the deposit facility to 4.25 percent and the lending facility to 5.75 percent. The policy was followed by a decrease in the Interbank Money Market (PUAB) interest rate to 4.76 percent. Loan interest rates also fell to 12.23 percent (Bank Indonesia, 2017). 
The value of the rupiah in 2016 strengthened by 1.39 percent reaching Rp. 13,130 per US dollar. Although it was held back by the election, the rupiah exchange rate strengthened in line with maintained macroeconomic stability and the implementation of a tax amnesty policy going well. The strengthening condition of the exchange rate caused inflation to remain below the 2016 inflation target range of 0.90 percent (qtq) (Bank Indonesia, 2017).

Throughout 2017, Bank Indonesia decided on a 7-Day Reverse Repo Rate BI rate of 4.25 percent with a fixed deposit facility of 3.59 percent and a lending facility of 5.00 percent. This consistent decision is due to Indonesia's economic growth in 2017 being very stable so that monetary policy through consistency in interest rates is seen as adequate to keep inflation and financial transactions at a healthy level (Bank Indonesia, 2018).

But the rupiah exchange rate in 2017 depreciated by 0.19 percent to Rp. 13,333 per US dollar. This is influenced by the strengthening of the US dollar globally which is the impact of sentiment on the planned tax reform in the US and anticipation of an increase in the Fed Fund Rate. While the inflation rate was lower than the previous year which was 0.70 percent or 3.72 percent. So, in 2017 the central bank will still loosen monetary policy through the interest rate channel because it is considered quite effective for the Indonesian economy (Bank Indonesia, 2018).

In contrast to 2017, in 2018 Bank Indonesia raised the BI 7-Day Reverse Repo Rate to 4.50 percent with the deposit facility to 3.75 percent and the lending facility to 5.75 percent. The BI 7-DRR level again increased in the second quarter, to 5.50 percent. This increase is in line with efforts to maintain the attractiveness of the domestic financial market and control the current account deficit within safe limits. This interest rate policy is supported by the strengthening of monetary operations strategies by strengthening the convergence of interbank money market interest rates with monetary policy rates (BI 7DRR) (Bank Indonesia, 2018).

The interest rate was again raised to 6 percent with a deposit facility of 5.25 percent and a lending facility of $6 / 75$ percent. This was done as an effort to reduce the current account deficit and maintain the attractiveness of domestic financial assets. Besides, the rupiah exchange rate continued to strengthen until the end of 2018 due to the large inflow of foreign capital. While the inflation rate did not go too far down to 3.03 percent (Bank Indonesia, 2018)

So it can be concluded from year to year, economic growth in Indonesia tends to increase due to the implementation of various policies implemented by the government in collaboration with Bank Indonesia as the central bank. The data on Indonesia's economic growth based on the Central Statistics Agency are as follows: 
INDONESIA'S ECONOMIC GROWTH

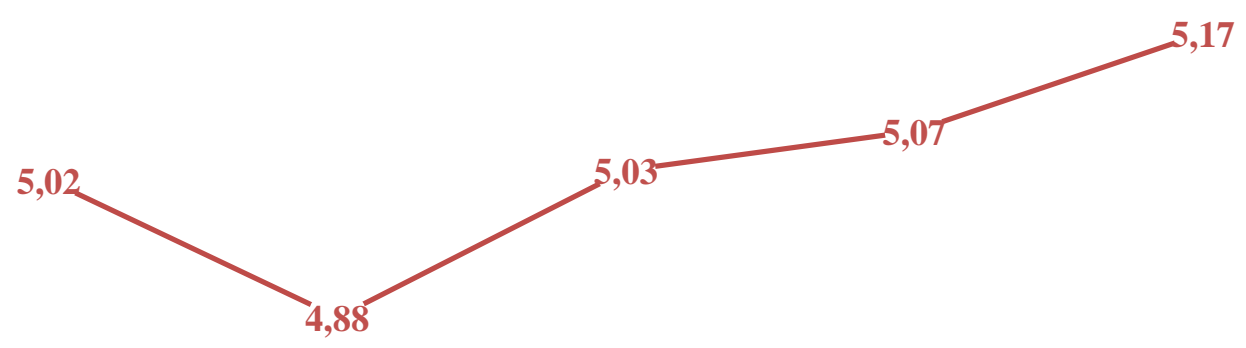

\section{4}

2015

2016

2017

2018

Figure 3. Data of Indonesia Economic Growth

Source: (Badan Pusat Statistik, 2019)

\section{Analysis of Indonesian and Malaysian Monetary Policy Concepts}

Monetary policy is a policy originating from the central bank in the form of controlling the amount of monetary and/or interest rates to achieve the desired economic goals (Mutiah, 2010). Monetary policy itself is seen as a strong instrument to achieve economic goals such as price stability, employment, the balance of payments and sustainable economic growth of the country (Herianingrum \& Syapriatama, 2016). Also, there are two classes of monetary policy, namely expansionary monetary policy to increase the money supply and contractive monetary policy to reduce the money supply. The central bank itself issued this monetary policy through three instruments, namely Open Market Operations (OMO), discount policy and legal reserve requirement (LRR) (Fikri, 2019).

From the above definitions, a common thread can be drawn, that monetary policy in Indonesia is very dependent on the policy of determining interest rates. Since 2005 until now, interest rates have become the main instrument used by Bank Indonesia in regulating the rise and fall of inflation. Further findings, it can be said that interest rates in influencing the rupiah exchange rate fluctuate. At least that can be seen from the development of the rupiah exchange rate during the last five years where in 2014 the rupiah exchange rate weakened against the United States dollar by 3.9 percent to Rp. 12,244 per US dollar.

Furthermore, in 2015 the rupiah strengthened again by 0.1 percent to Rp. 13,775 per US dollar. The rupiah exchange rate strengthened again by 1.39 percent reaching Rp. 13,130 per US dollar in 2016. The factor that caused the rupiah to strengthen is that Bank Indonesia lowered interest rates. Furthermore, in 2017, the rupiah exchange rate depreciated by 0.19 percent to Rp. 13,333 per US dollar, in 2017 Bank Indonesia continues to provide concessions for setting interest rate policies. As for 2018, the exchange rate will strengthen, this is because Bank Indonesia increases the value of interest rates which has an impact on the number of foreign investments that invest in Indonesia.

Interest rates are an important instrument in monetary policy in Indonesia. From the above explanation, the Indonesian economy continues to experience an increase which is influenced by monetary policy through the regulation of rising and falling interest rates carried out by Bank Indonesia. 
The above findings, following research conducted by (Wibowo, 2014) that monetary policy by applying the benchmark interest rate is a factor that affects the rupiah exchange rate in Indonesia and has an impact on economic growth in Indonesia.

As for monetary policy in Malaysia, as with Indonesia, monetary policy in Malaysia relies on interest rates. At least in the last five years namely 2014-2018, interest rates have greatly influenced the stability of the prices of goods in Malaysia. The Malaysian government always applies interest rates around 5 percent. As a result, the economy in Malaysia has continued to grow.

The influence of interest rates in stabilizing the prices of goods, both in Indonesia and in Malaysia, indicates that monetary policy between Indonesia and Malaysia has a similarity in which interest rates are the main instrument in controlling inflation in Indonesia and Malaysia. Thus, it can be concluded that the monetary policy instruments undertaken by the Indonesian government and the Malaysian government have in common, namely the use of interest rate instruments.

\section{CONCLUSION}

The purpose of a monetary policy adopted by a country is to achieve price stability, low unemployment rates, and sustainable economic growth. Through several channels such as interest rates, credit, exchange rates, asset prices, and expectations, will affect the inflation rate. So it will have an impact on the country's economic growth.

Although there are five monetary policy mechanism channels, the most effective monetary policy path is applied is the interest rate channel. Through a decrease in interest rates, the demand for credit will increase and then have an impact on lowering the cost of capital for companies to invest. So that it will increase consumption and investment activities.

Other than through the interest rate channel, other instruments implemented by the central bank in Indonesia include minimum mandatory reserves, Open Market Operations, discount facilities, and appeals. These instruments differ from Malaysia, which includes direct loans without bonds through open tenders, repo transactions, auction of Bank Negara Monetary Notes (BNMN), auction of Bank Negara Interbank Bills (BNIBs) and exchanging foreign currencies (FX).

The implementation of each monetary policy instrument is adjusted to the economic conditions of the country which are not only influenced by internal conditions but also external conditions such as trade conditions in the United States and China, even political conditions in the United States. Therefore, economic conditions in both Indonesia and Malaysia fluctuate, although they have tended to increase over the past five years.

\section{REFERENCES}

Ahmad, Z., \& Ismail, A. G. (2019). Alternative of Monetary Policy Indicator: Panel Data Analysis From Islamic Banks in Malaysia. Journal of Islamic Monetary Economics and Finance, 4(2), 279-292. https://doi.org/10.21098/jimf.v4i2.1017

Ahmadi, R. (2016). Metodologi Penelitian Kualitatif. Yogyakarta: Ar-Ruzz Media.

Antonio, M. S. (2014). VOLATILITAS PASAR MODAL SYARIAH DAN INDIKATOR MAKRO EKONOMI : Studi Banding Malaysia dan Indonesia. Bisnis Dan Manajemen, 1(1), 1-12. 
Ascarya, A. (2012). Alur Transmisi Dan Efektifitas Kebijakan Moneter Ganda Di Indonesia. Buletin Ekonomi Moneter Dan Perbankan, 14(3), 283-315. https://doi.org/10.21098/bemp.v14i3.360

Badan Pusat Statistik. (2019). Berita Resmi Statistik. Jakarta.

Bank Indonesia. (2015). Laporan Kebijakan Moneter Triwulan IV 2014. Jakarta.

Bank Indonesia. (2016). Laporan Kebijakan Moneter Triwulan IV 2015. Kuala Lumpur.

Bank Indonesia. (2017). Laporan Kebijakan Moneter Triwulan III 2016. Jakarta.

Bank Indonesia. (2018a). Laporan Kebijakan Moneter 2017. Jakarta.

Bank Indonesia. (2018b). Laporan Kebijakan Moneter IV. Jakarta.

Bank Indonesia. (2018c). Tinjauan Kebijakan Moneter Desember 2018. Jakarta.

Bank Negara Malaysia. (2015). Outlook and Policy in 2015. Kuala Lumpur.

Bank Negara Malaysia. (2016). Overview Policy. Kuala Lumpur.

Bank Negara Malaysia. (2018). Economic Report 2017/2018. Kuala Lumpur.

Bank Negara Malaysia. (2019a). Monetary Operations. Retrieved from http://www.bnm.gov.my/index.php?ch=en_fxmm_mo\&pg=en_fxmm_mo_overview $\& \mathrm{ac}=282$

Bank Negara Malaysia. (2019b). Monetary Policy in 2018. Kuala Lumpur.

Bosco, B., Parisio, L., \& Baldi, F. (2009). Long-Run Relations in European Electricity Prices. Journal of Applied Econometrics, 868(May 2009), 833-868. https://doi.org/10.1002/jae

CEIC Data. (2019). Malaysia Real GDP Growth. Retrieved from https://www.ceicdata.com/en/indicator/malaysia/real-gdp-growth

Chaidir, T. (2019). Info Artikel Kata Kunci: ABSTRAK. 1(1), 54-65.

Fikri, R. J. (2019). Monetary Transmission Mechanism Under Dual Financial System in Indonesia: Credit-Financing Channel. Journal of Islamic Monetary Economics and Finance, 4(2), 251-278. https://doi.org/10.21098/jimf.v4i2.1001

Herianingrum, S., \& Syapriatama, I. (2016). Dual Monetary System and Macroeconomic Performance in Indonesia. Al-Iqtishad: Journal of Islamic Economics, 8(1), 65-80. https://doi.org/10.15408/aiq.v8i1.2509

Magdalena, I. (2014). Analisis Efektivitas Transmisi Kebijakan Moneter Ganda Di Indonesia. Ekonomi Dan Keuangan, 2(11), 657-671.

Mutiah, A. (2010). Analisis Pengaruh Monetary Policy Shock Terhadap Jumlah Deposito Perbankan Islam Dalam Sistem Perbankan Ganda : Studi Kasus Indonesia Dan 
Malaysia. Jurnal Tazkia, 5(1), 21-38.

Naveed, M. Y. (2015). Impact of Monetary Policy Shocks in a Dual Banking System in Pakistan : A Vector Auto Regressive Approach ( VAR ). European Academic Research, II(11), 14684-14700.

Omer, M. (2019). Monetary Policy Pass-Through, Excess Liquidity and Price Spillover : a Comparative Study of Conventional and Islamic Banks of Pakistan. 5(2), 287-320.

Shah, S. M. A. R. (2019). the Credit Supply Channel of Monetary Policy Transmission Mechanism: an Empirical Investigation of Islamic Banks in Pakistan Versus Malaysia. Journal of Islamic Monetary Economics and Finance, 5(1), 21-36. https://doi.org/10.21098/jimf.v5i1.1046

Simanjuntak, M., \& Santosa, B. (2019). Perbandingan Efektivitas Mekanisme Transmisi Kebijakan Moneter Antara Jalur Suku Bunga Dengan Jalur Nilai Tukar Terhadap Sasaran Akhir Inflasi. Media Ekonomi, 25(1), 1. https://doi.org/10.25105/me.v25i1.5199

Subagyo, J. (2004). Metode Penelitian dalam Teori dan Praktek. Jakarta: PT Rineka Cipta.

Utomo, Y. P., \& Setiaji, B. (2012). Efektivitas Pengaruh Kebijakan Moneter. Jurnal Ekonomi Manajemen Sumber Daya, 1-14. Retrieved from http://publikasiilmiah.ums.ac.id/bitstream/handle/123456789/2846/1.pdf?sequence=1

Wibowo, B. (2014). Buddi Wibowo.pdf. 